\title{
UNINSURED MOTORIST INSURANCE: CALIFORNIA'S LATEST ANSWER TO THE PROBLEM OF THE FINANCIALLY IRRESPONSIBLE NIOTORIST
}

INTRODUCTION

\section{A. Nature of the Problem}

Because of the constant increase of motor vehicle traffic on California's streets and highways, the plight of innocent victims of traffic accidents caused by uninsured and financially irresponsible motorists has become a serious social problem. As of 1959 there were approximately seven million licensed drivers in California. About 88 percent of these drivers were covered by public liability insurance, and another 8 percent were uninsured but financially responsible. The remaining 4 percent-about 280,000 motorists-were uninsured and financially unable to pay damages in the event that they caused traffic accidents. Financial loss to the innocent victims of automobile accidents caused by uninsured and financially irresponsible motorists in California amounts to many thousands of dollars each year. ${ }^{1}$

Under California's Financial Responsibility Law, ${ }^{2}$ a motorist need not prove his ability to pay damages for personal injuries or property damage he may cause in a traffic accident until after he lias had one accident. Only then is he required to prove financial responsibility for future accidents by posting a bond or by showing that he carries public liability insurance.

Various solutions to the problem of the uninsured motorist have been proposed and adopted in other jurisdictions. Among them are compulsory automobile insurance, the Saskatchewan Plan (similar to workmen's compensation), and unsatisfied claim and judgment funds. ${ }^{3}$ A voluntary solution recently initiated by the insurance industry is uninsured motorist coverage, or insurance against uninsured motorists.

\section{B. Origin and History of Insurance Against Unirsured Motorists}

Insurance against uninsured motorists is variously called "Innocent Victim Coverage," "Uninsured Motorist Coverage," "Family Protection-Automobile Coverage," and "Family Protection Against Uninsured Motorists."

The history of uninsured motorist coverage began in January 1954, when a fer insurance companies added the "unsatisfied judgment" endorsement to their standard form automobile liability policies at preniums ranging from $\$ 5.00$ to $\$ 7.50$. This endorsement, a primitive form of uninsured motorist coverage, was payable only after the insured had reduced his claim against the uninsured motorist to judgment and after it was deternined that the judgment was uncollectible. Some of the limited endorsements provided that judgments by default were not covered. The limits of coverage were usually $\$ 5,000 / \$ 10,000$ for bodily injury,

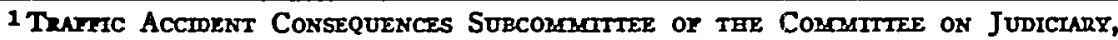
Final Repost to tel Calmforkia Legisiature (House Resolution 192, 1957) 11 (1959) [hereinafter cited as COMBrrtres REPORT].

2 CAT. VEH. CODE $\$ 8 \$ 16000-503$.

- For a concise sketch of each of the various plans, see Plummer, The Uncompensaled Automobile Accident Victim, 24 Ixs. CounseI J. 78 (1957).

1 Plummer, Hardling Claims Under the Uninsured Motorist Coverage, 1957 Irs. L.J. 494. 
and most endorsements did not cover property damage. ${ }^{5}$ The next step in the evolution of uninsured motorist coverage was the addition of protection against property damage caused by uninsured motorists. Later, some insurers agreed to pay certain classes of claims without their first being reduced to judgment. ${ }^{6}$

In October 1955 automobile insurers in New York State began offering, without additional charge, two forms of uninsured motorist endorsements to supplement automobile liability policies. These endorsements covered bodily injury only. ${ }^{7}$ One form was based on the assumption that the uninsured motorist was liable; the other, like the form currently in use in California, required proof of the uninsured motorist's liability.

In December 1956 the National Bureau of Casualty Underwriters and the Mutual Insurance Rating Bureau made available an uninsured motorist endorseinent to the family automobile policyholder. It was available to owners of private passenger cars only, and it afforded protection to the insured not only when he was an occupant of a vehicle, but also when lie was a pedestrian. ${ }^{8}$

In April 1957 one of the leading mutual insurers ${ }^{9}$ began issuing a type of uninsured motorist endorsement which provided for payments to the insured by scliedule where specified injuries were caused by the negligence of the uninsured motorist. ${ }^{10}$ This endorsement also paid 80 percent of both the insured's loss of earmings and his additional expenditures for household services. Nothing was paid for direct medical expenses or for pain and suffering. ${ }^{11}$

In May 1957 various insurance companies in New York State began issuing "innocent victim" policies to persons who did not own automobiles. The premiun was $\$ 11.00$ in metropohtan New York and $\$ 10.00$ "up-state." 12

Uninsured motorist insurance was first proposed as an alternative to compulsory insurance and state-operated unsatisfied judgment funds. New Hampshire in 1957 was the first state to require that uminsured motorist coverage be made a standard feature of every policy of automobile liability insurance issued in the state. $^{13}$ California was soon to follow suit.

\section{Califorria's Solution to the Problem}

In 1957, The Traffic Accident Consequences Subcommittee of the Committee on Judiciary of the California Assembly undertook a study of the problem of the uninsured motorist. ${ }^{14}$ Among the solutions considered and rejected were compulsory liability insurance, ${ }^{15}$ an unsatisfied claim and judgment fund plan, ${ }^{16}$ the Saskatchewan Automobile Accident Compensation plan, ${ }^{17}$ and Professor Albert A.

S Plummer, The Uncompensated Automobile Accident Victim, 24 INs. Counsex J. 78, 83 (1957).

o Plummer, Handling Claims Under the Uninsured Motorist Coverage, 1957 INs. L.J. 494. 7 Ibid.

8 Miller, The New "Uninsured Motorist" Endorsement to Family Automobile PoliciesThe 1960 Look, 24 INs. Counsex J. 134 (1957).

${ }^{9}$ State Farm Mutual Automobile Insurance Company.

10 E.g., loss of both hands or both feet or loss of sight of both eyes, $\$ 5,000$; loss of any two fingers of same hand, $\$ 1,000$.

11 State Farm Mutual Automobile Insurance Company, Form 9415.

12 Plummer, Handling Claims Under the Uninsured Motorist Coverage, 1957 INs. L.J. 494.

13 N.H. Rev. Stat. Ans. \$\$ 268:15, 412:2-a (1955); Murphy, Public Responsibility ard the Uninsured Motorist, 1959 INs. L.J. 491, 500.

14 COMOMITTEE REPORT.

16 Id. at $12,13$.

16 Id. at 13,14 .

17 Id. at 15. 
Ehrenzweig's proposed "Full Aid Insurance."18

The Subcommittee then directed its attention to a voluntary program of insurance against uninsured motorists, the plan which was ultimately adopted. The Subcommittee hearings revealed that most persons in California were under the erroneous behiefs that automobile public liability insurance was compulsory in California and that there were no uninsured motorists in the state; that many persons did not realize that most public liability insurance pohicies did not afford protection against loss resulting from accidents caused by uninsured motorists; and that many persons did not know that uninsured motorist coverage was offered by insurance companies. ${ }^{19}$ The Subcommittee concluded that the majority of insured motorists would take advantage of insurance against accidents caused by uninsured and financially irresponsible motorists if insured motorists were made aware that such coverage was available. ${ }^{20}$

Believing that a purely voluntary plan would not hatve the desired effect of bringing to each motorist's attention the availability of uninsured motorist coverage, members of the Subcommittee introduced Assembly bill 1836, which, when enacted into law after a minor revision by the Senate, ${ }^{21}$ added section 11580.2 to the California Insurance Code, effective as of September 18, 1959. (This statute is set forth in full in Appendix A.)

The new code section provides that all automobile bodily injury liability insurance policies issued or delivered in California shall include provisions for uninsured motorist coverage. ${ }^{22}$ It also permits the insured to be reimbursed independently of any other applicable insurance coverage, e.g., medical payments coverage. ${ }^{23}$ The statute further provides that the insured and insurer may by supplemental agreement waive uninsured motorist coverage. ${ }^{24} \mathrm{It}$ also permits the insurer to be subrogated to the rights of the insured against the uninsured motorist after the insurer pays a claim under the coverage..$^{25}$

An immediate effect of the addition of section 11580.2 to the Insurance Code has been a tremendous increase in the number of policyholders who carry uninsured motorist coverage. Prior to the enactment of section 11580.2, less than onefourth of all California motorists had uninsured motorist coverage. Today more than 90 percent are covered. ${ }^{28}$ There are indications, however, that the uninsured motorist coverage required to be offered by section 11580.2 is merely a temporary solution to the problem of the financially irresponsible motorist, pending further study of Professor Ehrenzweig's "Full Aid Insurance" plan or an automobile acci-

18 Id. at $15,16$.

10 Id. at 14 .

$20 \mathrm{Id}$. at 15.

21 The Senate Committee on Insurance and Financial Institutions amended Assembly bill 1836 by striking out the following language which previously appeared at the end of subsection (d) of the enacted statute, following the words "Vehicle Code": "The applicable limits hereunder shall apply only as excess insurance over any other liability insurance available to such insured, and this insurance shall then apply only in the amount by which the applicable limit of liability under this endorsement exceeds the sum of the applicable limits of liability of all such other insurance. As used herein, 'such other insurance' is not intended to include coverage for medical payments, personal accident or sickness disability, disability income, or any other separate or individual coverage other than liability insurance available to the insured."

22 CAL. INS. CODE $\$ 11580.2$ (a).

23 Car. INS. CODE $\$ 11580.2(f)$.

24 CAT. INS. CODE $\$ 11580.2$ (a).

25 CAI. INS. CODE $\$ 11580.2$ (e).

20 Interview with Mr. M. J. Lucchesi, Divisional Superintendent of Claims, State Farm Mutual Automobile Ins. Co., in Berkeley, Calif., on April 13, 1960. 
dent compensation plan similar to workmen's compensation. Governor Brown in his inaugural message on January 5,1959, called for a study of the possibility of compensation without regard to fault in automobile accident cases. ${ }^{27}$ Nevertheless, insurance agamst uninsured motorists, together with the Financial Responsibility Law, is California's present answer to the problem of the financially irresponsible motorist.

\section{The Solution Generates Problems of Its Own}

With the great increase in the number of California drivers carrying insurance against uninsured motorists, ${ }^{28}$ plaintiffs' attorneys, defense counsels, and claims adjusters will be faced with new practical and legal problems generated by the interaction of the provisions of the Standard Form Uninsured Motorist Endorsement and soinetimes conflicting provisions of California Insurance Code section 11580.2. The remainder of this Comment will be devoted to discussing some of these problems and suggesting possible solutions.

II

THE STATUTE AND THE STANDARD FORM

\section{A. The Standard Form}

Under the Standard Form Uninsured Motorist Coverage Endorsement, ${ }^{29}$ the insurer agrees to pay the insured all sums that he shall be legally entitled to recover as damages for bodily injury sustained in accidents arising out of the ownership, maintenance, and use of an uninsured automobile. ${ }^{30}$ Property damage is not covered.

The persons covered by the Standard Form are any persons designated as named insureds and, while residents of the same houseliold, the spouse of any named insured and the relatives of either sponse. ${ }^{31}$ These persons qualify as insureds whether or not they occupy the insured automobile at the time of injury. They are covered even while pedestrians. Regardless of how many automobiles are owned by the named insured or relatives who are members of his household, only one uninsured motorist endorsement is needed to protect members of this class of insureds. ${ }^{32}$

A second class of insureds includes any other person occupying an insured automobile, ${ }^{33}$ and a third class includes a lusband laving a claim for the loss of his wife's services or a parent having a claim for expenses incurred and services lost due to injury to a child. ${ }^{34}$

For the purpose of determining who quatifies as one of the second class of insureds, an insured automobile is defined, with certain exceptions, as an automobile owned by the named insured or his spouse if a resident of the same house-

27 COMMTrTEE REPORT at 10.

28 See text accompanying note 26 supra.

29 National Bureau of Casualty Underwriters and Mutual Insurance Rating Bureau Standard Form Uninsured Motorist Endorsenent (Family Protection Coverage Endorsenent), A615a, AL8589a [hereinafter cited as Standard Form]. Many of the major autonobile insurance companies issue policies having language identical with that of the Standard Form.

30 Standard Form, Insuring Agreement I.

31 Standard Form, Insuring Agreement II(a)(1).

32 Standard Form Insuring Agreements I and II(a)(1) taken together lead to this conclusion.

${ }^{33}$ Standard Form, Insuring Agreement II(a)(2).

34 Standard Form, Insuring Agreement II(a) (3). 
hold, a temporary substitute automobile, and any other automobile while being operated by the named insured or his spouse if a resident of the same household. ${ }^{35}$

An uninsured automobile is defined as one not covered by any applicable bodily injury liability insurance or bond, or a hit-and-run automobile, but does not include an automobile owned by the named insured or members of his household, automobiles operated by self-insurers, government-owned automobiles, or certain classes of other vehicles not generally thought of as automobiles. ${ }^{36}$

Under the new coverage the insured may file suit against the uninsured motorist, but he must not settle the claim or prosecute it to judgment without the written consent of the insurer. ${ }^{37}$ Disputed claims between the insurer and the insured concerning the liability of the uninsured motorist and the amount of damages are to be submitted to arbitration..$^{38}$

To the extent of its payment, the insurer is given a right of subrogation against the uninsured motorist. ${ }^{39}$ The insurer, therefore, does not really become a liability msurer of the uninsured motorist. Although California Insurance Code section 108(d) classifies uninsured motorist coverage as a type of liability insurance, the new coverage is actually more in the nature of a surety bond.

\section{B. The Rule of the Wildman Case}

In order to comprehend many of the problems presented by the interaction of California Insurance Code section 11580.2 and the Standard Form, a basic understanding of the rule set forth in the case of Wildman v. Government Employees' Ins. $\mathrm{Co}^{40}$ and its progeny is necessary.

Old California Velicle Code section $415^{41}$ constituted a part of California's Financial Responsibility Law. It provided, inter alia, that a policy of automobile liability insurance should insure the person named therein and any other person using the described vehicle with the permission of the named insured. In the Wildman case, the insurer issued a somewhat ambiguous endorsement to a policy of automobile liability insurance purporting to restrict coverage to the named insured and members of his immediate family and to suspend operation of the policy where anyone other than the named insured or a member of hiss family was driving the described automobile. A non-member of the family negligently injured the plaintiff while driving the described automobile with the permission of the named insured, and the insurer denied coverage. The Supreme Court of California held that the ambiguous endorsement should be construed against the insurer. Of even more importance was a dictum to the effect that inasmuch as sections $402^{42}$ and 415 set forth the public policy of California, such laws must be considered a part of every policy of automobile liability insurance even though the insurance policy itself does not specifically make such laws a part of the policy. ${ }^{13}$

35 Standard Form, Insuring Agreement II(b).

36 Standard Form, Insuring Agreement II(c).

37 Standard Form, Exclusion (b).

38 Standard Form, Condition 6.

39 Standard Form, Condition 7.

4048 Cal. 2d 31, 307 P.2d 359 (1957).

41 In 1959, the California Vehicle Code was completely overhauled. The applicable portion of "old" $\$ 415$ is now found in $\$ 16450$ of the 1959 revision of the Vehicle Code.

12 "Old" $\$ 402$ provided that the owner of an automobile was vicariously liable for personal injuries and property damage caused by the driver.

$4348 \mathrm{Cal} .2 \mathrm{~d}$ at 39,307 P.2d at 364 . 
In Bonfils v. Pacific Auto. Ins. Co., ${ }^{44}$ a restrictive endorsement provided that a policy of automobile liability insurance should be null and void if the described automobile were operated by any person other than the named insured. The District Court of Appeal extended the rule of the Wildman case and held that the endorsement was invalid in that section $\mathbf{4 1 5}$ of the Vehicle Code must be made a part of every policy of automobile liability insurance issued by an insurer, even though the policy of insurance was not issued to prove financial responsibility under the Financial Responsibility Law. ${ }^{45}$

Since the language of California Insurance Code section 11580.2 is mandatory, ${ }^{46}$ it seems reasonable to assume that its mandatory provisions will also be read into non-complying policies by the courts, and that express provisions of insurance policies in derogation of the mandatory statutory provisions will not be enforced. This should be especially true in those policies of insurance which contain the customary clause expressly providing that policy terms in conflict with statutes are amended to conform to such statutes.

\section{May Policyholders Effectively Waive Uninsured Motorist Coverage?}

Assuming that the rule of the Wildman case apphies to uninsured motorist insurance, it is interesting to speculate on the effect that the waiver provision of Insurance Code section 11580.2 may have on policies of automobile liabihity insurance issued in California. The statute provides for mandatory uninsured motorist coverage in every policy of automobile liability insurance issued or delivered in California "provided, lowever, that the insurer and the insured may by supplemental agreement waive application of the provision covering damage caused by an uninsured motor vehicle." 47

Let us suppose that an iusurer issues a policy of automobile liability insurance in California having no uninsured motorist provision and that the insured is subsequently injured by an uninsured motorist. By applying the rule of the Wildman case, the provisions of section 11580.2 may be read into the policy, and the insured may have a valid uninsured motorist claim against the insurer. Even if the insured had specifically requested that uninsured motorist coverage be omitted from his policy, he may still have a valid uninsured motorist claim against the insurer. Although the statute provides that the insured may waive the coverage, in this situation he did not effectively do so, for the statute requires that the waiver be made by "supplemental agreement." 48

The requirenent that the waiver must be made by supplemental agreement guarantees that any waiver of uninsured motorist coverage will be at the option of the insured, and it prevents insurers from forcing a waiver by inclusion of a waiver proviso in the policy itself. Therefore, every policy of automobile hability insurance when first issued includes uninsured motorist coverage for at least the period between the time of issuance and the time of waiver by supplemental agreement.

41 165 Cal. App. 2d 152, 331 P.2d 766 (1958).

15 Because of a 1957 amendment to "old" $\$ 415$ of the Vehicle Code (Cal. Stats. 1957, ch. 1654, p. 3034, \& 1), the statutory mandate of "old" \& 415 (new \$16450) now applies only" to policies of liability insurance certified as proof of financial responsibility. See McFarland $v$. New Zealand Ins. Co., 176 A.C.A. 468, 1 Cal. Rptr. 482 (1959).

16 CAI. INS. CODE $\$ 11580.2$ (a) provides that "No policy of bodily injury liability insurance ... shall be issued ... unless the policy contains $[a$ provision for uninsured motorist coverage] ...." (Emplrasis added.)

17 CAL. INS. CODE $\$ 11580.2(\mathrm{a})$.

$48 \mathrm{Ibid}$. Query whether in this situation the insured is estopped from invoking the statute. 
However, as a practical matter, it is doubtful that any waiver by supplemental agreement is entirely effective so far as the insurer is concerned. The problem arises because of the peculiar wording of section 11580.2. Subsection (b) provides that "as used in (a) above ... the term 'insured' means the named insured and the spouse of the named insured and relatives of either while members of the same household ... and any other person while in or upon ... an insured motor vehicle." The unqualified word "insured" is used in subsection (a) only once, and that is where it is provided that "the insured may by supplemental agreement waive ...." Thus, it appears that a fairly formidable group of persons would be required to execute a waiver that would be entirely effective to protect the insurer. For example, if a husband and wife are named msureds, a vahd waiver executed by the husband would not seem to constitute a waiver for the wife, ${ }^{49}$ their minor children, relatives who are members of their household, or any other occupant of the insured automobile. Since by statutory definition all of these people are insureds for the purpose of executing a waiver and since all of them did not agree to waive the coverage, the coverage would continue to exist as to all of them, in spite of the husband's waiver.

The attorney general of California, however, came to the opposite conclusion when asked by county counsel for an official opinion on the question of whether or not the county board of supervisors could effectively waive uninsured motorist coverage as to county vehicles. The attorney general requested comments from various government and insurance organizations and basing his opinion largely on the comments from members of the insurance industry, who would naturally favor a construction making the waiver of the named insured binding against all insureds, concluded that the board of supervisors (as the named insured) might execute an effective waiver, noting that "only in the case of memoranda from some of the governmental organizations, were doubts or a contrary view expressed."

Until the courts have passed on the issue or until the legislature enacts a clarifying amendment, adjusters, insurance counsels, and plaintiffs' attorneys should all be aware that a waiver problem exists and be prepared to deal with it. To obtain maximum protection from the supplemental waiver agreement, insurers who now follow the practice of permitting the supplemental agreement to be executed by only one of the named insureds should in the future insist that the supplemental agreement be executed by all named insureds, their spouses, the relatives of either who are residents of the same household, and if practicable all other persons known to occupy the insured vehicle on a regular basis.

\section{Other Consequences of the Wildman Rule}

If the rule of the Wildman case is applied to section 11580.2 , it may also have the effect of expanding the coverage provided by the Standard Form in two minor respects. Insuring Agreement II(b) of the Standard Form provides that "the term 'insured automobile' shall not mclude ... (i) an automobile while used as a public or livery conveyance." The statute, lowever, provides that no policy of insurance covering liability arising out of the ownership of any motor vehicle shall be issued without provision for uninsured molorist coverage. ${ }^{51}$ Insuring Agreement II(c) provides that the term "uninsured automobile" shall not include "(vi) a farm type

${ }^{19}$ As to the wife, the insurer might contend that the husband, as the wife's agent, also waived her coverage.

5035 Ops. Cal. Att'y Gen. 71, 74 (1960).

51 CaI. INS. CODE $\$ 11580.2(a)$. 
tractor or equipment designed for use principally off public roads, except while actually upon public roads." This exception is not found in the statutory definition of "uninsured motor vehicle." ${ }^{2}$ It is therefore probable that these two provisions of the Standard Form are void in that they purport to restrict coverage to a narrower class than the statute permits.

\section{E. Other Insurance}

One of the most unsettled areas of insurance law today is the problem presented where more than one policy of insurance covers the same loss. ${ }^{53}$ In order to resolve in advance the problem of which insurer shall bear the loss, insurers customarily include in their policies one or more "other insurance" clauses. Generally these clauses fall into three categories: (1) pro-rata clauses, which provide that the insurer will pay its pro-rata share of the loss in the proportion which its policy liability himits bear to the aggregate liability coverage; (2) excess clauses, which purport to limit the insurer's loss to that in excess of any loss of the insured covered under other valid and collectible insurance; and (3) escape clauses, which purport to afford no coverage where there is other insurance available.

Where two policies of insurance which cover the same loss both contain pro-rata clauses, the "other insurance" clause of eacln policy is generally harmonious with that of the other. But where two policies of insurance covering the same loss both contain nutually exclusive excess or escape clauses, conflict is apparent, and the law is in a state of confusion. In such situations, judicial decisions involving the construction of conflicting "other insurance" clauses "point in all directions," the only certainty being that the insured will not be denied a recovery.

To remedy this confusion it has been suggested that a statute be enacted prescribing a standard "other insurance" clause, ${ }^{55}$ and this is what has been done in the himited area of uninsured motorist coverage. However, section $11580.2(\mathrm{c})(2)$, which sets forth a standard "other insurance" clause, has not solved the problem of conflicting clauses. Most insurers still continue to issue policies having "other insurance" clauses dissimilar to the one in the statute, because they continue to use the Standard Form.

The Standard Form was drafted prior to the enactment of section 11580.2. It contains two pro-rata clauses, one escape clause, and one excess clause, whereas the statute contains a single escape clause. (The relevant clauses of the statute and the Standard Form are set forth in Appendix B.) This multiplicity of clauses has caused sharp conflicts, and in order to illustrate how these conflicts arise and to suggest possible solutions, the following hypothetical situations are offered. Unless otherwise stated, assume the limits of the uninsured motorist coverage of both policies are $\$ 10,000$ for injury to any one person and $\$ 20,000$ for injury to more than one person, and that both insurers use the Standard Form.

\section{Excess-Escape v. Pra-rata}

Able is the named insured under a policy issued by Company $A$. While occupying a car owned by Baker, the named insured under a policy issued by Company $B$, Able is injured to the extent of $\$ 12,000$ by an uninsured motorist. With respect to

52 CAI. INS. CODE $\$ 11580.2$ (b).

53 See generally, Note, 5 U.C.L.A.L. Rev. 157 (1958); Note, 7 ALA. L. Rev. 409 (1955).

54 Oregon Auto Ins. Co. v. United States Fidelity \& Guaranty Co., 195 F.2d 958, 959 (9th Cir. 1952).

min Note, 5 U.C.L.A.L. REv. 157, 164 (1958). 
Company $A$ 's policy, Able was at the time of injury "occupying an automobile not owned by a named insured under this endorsement." Therefore, the excess and escape clauses of Company $A$ 's policy appear to apply. With respect to Company $B$ 's policy, Able is "any other person while occupying au insured automobile." ${ }^{60}$ Able therefore qualifies as an insured under Company $B$ 's policy. But from Company $B$ 's viewpoint, Able is "a named insured under similar insurance available to him;" therefore, the pro-rata clause found in paragraph (2) of Company $B$ 's policy appears to apply. The excess-escape clause of Company $A$ 's policy and the pro-rata clause of Company $B$ 's policy are repugnant to each other. Fortunately, the statute yields a solution to this problem, for it provides that the uninsured motorist coverage does not apply "to bodily injury of the insured sustained while in ... an automobile other than the described automobile if the owner thereof has [other uninsured motorist insurance] . ..." to the escape clause of the statute and require Company $B$ to bear a loss of $\$ 10,000$.

Able then files a claim for his excess damages $(\$ 2000)$ with Company $A$. But as paragraph (1) of policy $A$ 's "other insurance" clause provides that Company $A$ 's excess exposure shall apply "only in the amount by which the applicable limit of this endorsement $[\$ 10,000$ under policy $A]$ exceeds the applicable limits of liability for all such other insurance $[\$ 10,000$ under policy $B], "$ the excess coverage afforded to Able under his own policy is zero $(\$ 10,000$ minus $\$ 10,000)$. As this type of excess clause operates as an escape clause when the limits of "other insurance" are equal to or greater than the limits provided by the other policy in question, and as the statute provides a statutory escape clause for Company $A$, Company $A$ should be able to deny coverage as to Able's excess damages. Therefore Company $B$ bears a loss of $\$ 10,000$; Able bears a loss of $\$ 2000$; and Company $A$ 's coverage is not applicable. The above fact situation is one which will be frequently encountered, and the statute provides a convenient solution.

\section{Pro-rata v. Pro-rata}

Baker owns both a Ford and a Buick. Company $F$ insures the Ford, Company $B$ insures the Buick, and Baker is the named insured under both policies. While occupying his Ford, Baker is injured to the extent of $\$ 12,000$ by an uninsured motorist. Under both policies, Baker qualifies as "a named insured under similar insurance available to hin;" therefore, the pro-rata clauses found in paragraph (2) of both policies appear to apply. As the two pro-rata clauses are in harmony, it seems clear that in the absence of a statuie to the contrary, each insurer should be required to contribute $\$ 5000$ and that Baker must bear a loss of $\$ 2000$.

However, Company $B$ may possibly be able to invoke section 11580.2 and deny coverage. As to Company $B$, Baker was occupying "an antomobile other than the described automobile," the owner of which had "insurance similar to that provided in this section." By invoking these words of the statute and possibly a clause of the insurance contract providing that "policy terms which are in conflict with the statutes of the State ... are hereby amended to conform to such statutes," Company $B$ may contend that its coverage does not apply.

In the first situation (excess-escape v. pro-rata) the statute provided a welcome guide-post where decided cases did little more than "point in all direc- 
tions." 59 But here, where the law of "other insurance" had previously been clear, the statute serves to muddy the waters. As the probable intention of the legislature was that the statute should be resorted to as a tool to clarify the law rather than one to confuse it further, the ends of justice will best be served if the courts refuse to resort to the statute in situations where the "other insurance" provisions of both policies are in harmony. Otherwise the reasonable expectations of the parties will be defeated. Neither justice nor the policy of the law is served by giving one insurer a windfall at the expense of the other where the "other insurance" clauses of each contemplate pro-rating the loss between the two.

\section{Excess-escape v. Excess-escape}

Baker owns both a Ford and a Buick. Company $F$ insures the Ford and Company $B$ insures the Buick, and Baker is the named insured under both policies. Uncle Abe is a relative of Baker and a member of his household. While occupying an automobile of a friend who does not carry uninsured motorist coverage, Uncle Abe is injured by an uninsured motorist to the extent of $\$ 12,000$. As Uncle Abe is a qualified relative of Baker, he becomes an insured both under Company $B$ 's policy and under Company $F$ 's policy. Under both policies he is "occupying an automobile not owned by a named insured;" therefore, the excess and escape clauses found in paragraph (1) of both pohicies appear to apply. Here the "other insurance" clauses of the two policies are mutually exclusive and repugnant to each other, for if both were to be applied Uncle Abe would be left without any insurance protection whatever. Section 11580.2 is of no assistance in this situation, because the owner of the automobile in which Uncle Abe was injured does not have "insurance similar to that provided in this section." The fairest solution would seem to be to disregard the excess and escape clauses found in paragraph (1) of both policies and to give effect to the catch-all pro-rata clauses of paragraph (3) of both policies, pro-rating the loss between the two companies. As paragraphs (1) cannot be applied and as paragraphs (2) do not purport to apply, Uncle Abe should recover the full $\$ 12,000$, rather than the mere $\$ 10,000$ to which he would be relegated under the limiting language of paragraphs (1) and (2).

\section{Excess v. Pro-rata, Different Policy Limits}

Able, the named insured under a policy having limits of $\$ 10,000 / \$ 20,000$ issued by Company $A$, is injured to the extent of $\$ 7000$ by an uninsured motorist while occupying a car owned by Baker. Baker is the named insured under a policy having limits of $\$ 5,000 / \$ 10,000$ issued by Company $B$. With respect to Company $A$ 's policy, Able was at the time of injury "occupying an automobile not owned by a named insured under this endorsement;" therefore, the excess clause found in paragraph (1) of Company $A$ 's policy appears to apply. But with respect to Company B's policy, Able was at the time of injury "a named insured under similar insurance available to him;" therefore, the pro-rata clause found in paragraph (2) of Company B's policy also appears to apply. The excess clause of Company $A$ 's pohicy and the pro-rata clause of Company B's policy are repugnant to each other. But since Able was occupying "an automobile other than the described automobile" under the policy of Company $A$, the owner of which had "insurance similar to that provided in this section," the statute provides that the insurance coverage provided by Company A's policy "does not apply." The courts therefore should

59 Oregon Auto Ins. Co. v. United States Fidelity \& Guaranty Co., 195 F.2d 958, 959 (9th Cir. 1952). 
give effect to Company $A$ 's excess clause and disregard Company $B$ 's pro-rata clause, and permit Able to recover $\$ 5000$ from Company $B$.

Is Able also entitled to recover an additional $\$ 2000$ from Company $A$ ? If the literal words of the statute are followed, he is not. The escape clause of the statute provides that Company A's policy "does not apply." But if the language of the policies is to prevail, Able is entitled to recover $\$ 2000$ from Company $A$ by virtue of the excess clause of paragraph (1). Here the Standard Form is more hiberal to the insured than the statute. May the insurer invoke the Wildman rule to protect itself from its insured by subordinating the policy provisions to the terms of the statute? The answer should be no. The Wildman rule is a device to protect the insured-not the insurer. Furthermore, the probable intention of the drafters was that the "other insurance" clause of the statute was to apply for the purpose of resolving "other insurance" disputes between insurers-not for the purpose of limiting the rights of insureds. As Able's own policy of insurance purports to provide him with excess coverage, he should definitely be entitled to recover the $\$ 2000$ excess damages notwithstanding the limiting language of the statute.

\section{Conclusion}

Like other provisions of the statute, the "other insurance" provision generates problems of its own. However, it more than makes up for its defects by providing a ready solution for the most common "other insurance" problem likely to arise under the new coverage: namely, the "excess-escape v. pro-rata" conflict which occurs when the named insured under one policy is injured while occupying a car owned by another named insured under another policy. The present "other insurance" provision of the statute is thus one of its inany desirable features. The legislature slould render it even more desirable by enacting a clarifying amendment designed to eliminate the new areas of confusion it has created.

\section{F. Subrogation}

When the insurer pays an uninsured motorist claim, section 11580.2 provides that the insurer is entitled to be subrogated to the extent of its payment to the rights of the insured against the uninsured notorist. ${ }^{60}$ The subrogation of the insured's personal injury claim represents a departure from the common law rule that personal tort claims were neither assignable nor subject to subrogation. ${ }^{61}$ Prior to the enactment of California Insurance Code section 11580.2, the originators of uninsured motorist insurance had devised a "trust agreement" which provided that upon payment by the insurer, the insured held in trust for the insurer his rights of recovery against the uninsured motorist. The insured further agreed to assign to the insurer the proceeds of any settlement or judgment. The question of whether or not the trust agreement was an invalid attempt to assign a personal injury claim has probably become moot, since the statute now expressly authorizes subrogation. The trust agreement, however, is still found in Condition 7 of the Standard Form.

Although the statute provides that the insurer is entitled to become subrogated to the rights of the insured against the uninsured motorist to the extent of the insurer's payment, it is not clear how the uninsured motorist's assets should be distributed when the insured's damages for personal injuries exceed the coverage

60 CaI. INS. CODE $\$ 11580.2(\mathrm{e})$.

61 Aetna Life Ins. Co. v. J. B. Parker \& Co., 96 Tex. 287, 72 S.W. 168 (1903) ; 3 Ax. Jur., Assignments $\$ 30$ (1936). 
provided by the policy. For example, assume that the insured's damages are $\$ 12,000$. The insurer pays the insured's claim under the policy $(\$ 10,000)$ and thus becomes subrogated to the rights of the insured against the uninsured-motorist to the extent of $\$ 10,000$. The uninsured motorist has collectible assets of $\$ 3,000$. How should the $\$ 3,000$ be divided between the insurer and the insured?

There are at least four possible solutions: (1) the insurer has first claim to the assets and the insured is entitled to the remainder, if any; (2) the insured has first claim to the assets and the insurer is entitled to the remainder, if any; (3) the assets are to be pro-rated between the insured and the insurer in proportion to their respective claims; (4) priority goes to whoever first perfects a lien by judgment or execution against the debtor's assets according to the law of creditors' remedies. Neither the statute nor the Standard Form indicates which of the above answers is the correct one. A fair argument can be nnade for each of the four possible rules, ${ }^{62}$ and it is uncertain which one the courts will accept.

A further subrogation problem is presented where the insured is imjured by two negligent tortfeasors, one of whom is insured and the other is not. Section 11580.2 (e) provides that an insurer who pays an unimsured motorist claim shall be subrogated to the rights of the insured "against the person causing such injury ...." Where two persons cause the injury, only one of whom is insured, the insurer is apparently subrogated to the imsured's rights against the insured tortfeasor as well as the uninsured tortfeasor. In these circumstances, the insured may elect to be paid either under his own uninsured motorist coverage or under the insured tortfeasor's bodily injury liability coverage. If the insured should elect to be paid

62 (1) Argusment that the insurer should have priority to the uninsured motorist's assets: The purpose of uninsured motorist coverage is to guarantee that the insured will obtain compensation for his personal injuries which will be at least equal to the amount he would be entitled to recover under a policy of liability insurance having the minimum limits which could he certified as proof of financial responsibility. This amount could not exceed $\$ 10,000$; therefore the insurer should be entitled to recoup the first $\$ 10,000$ of the uninsured motorist's assets before the insured is entitled to anything. The insured pays a reduced premium in consideration of giving the insurer a right of subrogation. Furthermore, the Standard Form provides that the insured shall hold in trust for the henefit of the insurer all rights of recovery which he shall have against the uninsured motorist. To allow the insured to assert priority over the insurer would be to allow a trustee to defeat the interests of his cestui que trust.

(2) Argument that the insured shousld have priority to the uninsured motorist's assets: The function of the insurer writing uninsured motorist coverage is to assume those obligations which the uninsured motorist's liability insurer would have to the insured. If the uninsured motorist were insured, his insurer would be liable to the insured to the extent of $\$ 10,000$ and the insured would still have a claim against the tortfeasor which could be collected out of his assets. The insurer is paid a premium to assume this risk and ought not be permitted to defeat the interest of the insured who paid it. Furthermore, as the policy is ambiguous (or at best silent) as to how this conflict should be resolved, the ambiguity should be construed against the insurer and in favor of the insured.

(3) Argument that the assets should be pro-rated: As neither the statute nor the Standard Form indicates how the conflict ougbt to be resolved, a court should resort to principles of equity and justice in resolving the dispute. Pro-rating the assets between the insurer and the insured is the solution fairest to both parties.

(4) Argument that priority goes to whoever first perfects a lien: As neither the statute nor the Standard Form resolves the issue, the situation is merely one where two unsecured creditors have claims against an insolvent debtor. Whichever creditor is the more diligent in perfecting a hen by judgment and/or execution will gain priority.

This solution, however, is impractical, because insurance companies exercising their subrogation rights make a practice of bringing suit in the name of the insured and because an insured bringing the suit himself might be deemed to hold at least part of the proceeds in trust for the insurer. 
under his own uninsured motorist coverage and if the insured's damages for personal injuries are within the policy limits of the uninsured motorist coverage, the insurer would probably cloose to setile the matter with the insured tortfeasor's liability insurer in much the same way as it would settle a subrogated claim for a collision loss. But where the insured's damages for personal injuries exceed the policy limits of the uninsured motorist endorsement as well as the policy limits of the insured tortfeasor's bodily injury coverage, a priorities problem arises between the insured and his insurer that is similar to the one previously discussed. ${ }^{\text {} 3}$

Until these priorities problems are resolved either by litigation or legislation, claims managers, insurance counsels, and plaintiffs' attorneys will have to exercise careful judgment in deciding which position to take in any given case. In the opimon of this writer, insurers, in the interest of good customer relations, ought to resolve these issues in favor of the insured where the sum involved is small. Where larger amounts are involved a compromise in the nature of a pro-ration appears desirable.

\section{G. Workmen's Compensation}

Where the insured is entitled to receive workmen's compensation for an injury inflicted by an uninsured motorist, other problems arise. For example, assume that a truck driver employed by a bakery is injured by a negligent third party while the driver is making deliveries. The driver is entitled to vorkmen's compensation benefits either from the bakery (if a self-insurer) or from the bakery's compensation carrier ${ }^{64}$ He may also bring a tort action against the negligent driver ${ }^{65}$ In most cases the damages recoverable in tort will be greater than the compensation allowed by the workmen's compensation laws.

Under California's workmen's compensation law, the employer or the employer's compensation carrier has a right of subrogation against third party tortfeasors to the extent that a compensation payment is made, or a right of credit to the extent of a recovery against the third party by the employee. ${ }^{\text {ib }}$ If the third party tortfeasor has liability insurance, his liability insurer must respect the subrogation claim of the compensation carrier when settling the claim of the employee. But where the third party tortfeasor is an uninsured motorist and the employee is covered by an uninsured motorist endorsement, three distinct problems arise: (1) is the compensation carrier subrogated to the employee's right of recovery against the uninsured motorist insurer; (2) to what extent may the employee recover under the uninsured motorist endorsement; (3) in the event of payment to the insured by both the compensation carrier and the uninsured motorist insurer, which of the two insurers has a prior claim to the assets of the tortfeasor, against whom both are subrogated? The answers to these questions may be found, in part, in section $11580.2(\mathrm{c})(4)$, which provides:

The insurance coverage provided for in this section does not apply ... (4) In any instance where it would inure directly or indirectly to the benefit of any workmen's compensation carrier or to any person qualified as a self-insurer under any workmen's compensation law.

63 See text at note 62 supra.

64 See generally Division 4 of the California Labor Code.

65 The workmen's compensation law does not abrogate the employee's common law tort action against negligent third parties.

${ }^{66}$ CAI. LAB. CODE $\S \S 3850-63$. 


\section{Subrogation Rights of Compensation Carrier Against Uninsured Motorist Insurer}

Compensation carriers are accustomed to asserting subrogation claims against liability insurers of third party tortfeasors. Therefore, where the third party tortfeasor is an uninsured motorist, it is likely that many compensation carriers will attempt to assert subrogation claims against the uninsured notorist insurer of the employee on the theory that such an insurer takes the place of the tortfeasor's liability insurer. But simce section 11580.2 provides that uninsured motorist insurance does not apply in any instance where it would inure to the benefit of any workmen's compensation carrier, it seems clear that uninsured motorist insurers can take refuge in the statute and deny the subrogation clains of compensation carriers.

\section{Exient of Employee's Recovery Under Uninsured Motorist Coverage}

Uninsured notorist endorsements generally contain policy provisions purporting to reduce the amount payable under the endorsement by the amounts paid and payable under the workmen's compensation laws. Such provisions would appear to be valid under the statute, since section $11580.2(\mathrm{c})(4)$ provides that uninsured motorist insurance does not apply in any instance where it would inure to the benefit of a compensation carrier. In order to determine the extent of the employee's recovery under uninsured motorist coverage, it must be determined under what circumstances the proceeds of uniusured motorist caverage wauld iuure to the benefit of a compensation carrier.

It is submitted that uninsured motorist insurance never inures to the benefit of a compensation carrier and would nat so inure even in the absence of section 11580.2. Although the workmen's compensation law gives the compensation carrier a right of subrogation against a third party tortfeasor and by implication against the tortfeasor's hability insurer, it does not purport to give the conıpensation carrier a right of subrogation against an insurer of the employee. As the employee's clain under the uninsured motorist coverage is a contract right against his own insurer-not a tort claim against a third party-it is unlikely that uninsured motorist insurance would have inured to the benefit of a compensation carrier even prior to the enactment af section 11580.2.

But it is impossible to account for the existence of subsection (c) (4) except on the theory that the drafters assumed that a right of subrogation had previousiy existed. In no other way could such a recovery "inure directly or indirectly to the benefit of a workmen's compensation carrier." The attorney general of California apparently agrees that a right of subrogation did not previously exist and that the drafters erroneously assumed that it did exist. But on the theory that the drafters intended to permit uninsured motorist msurers to reduce their losses by the amounts payable under workmen's compensation laws, he has nevertheless upheld the validity af an uninsured motarist provision (not the Standard Form) which provided:

Any loss payable under the terms of this endorsement to or for any person shall be reduced by the amount paid and the present value of all amounts payable to him under any workmen's compensation law, exclusive of non-occupational disability benefits. ${ }^{67}$

67 35 Ors. CaL. Atr'y Gen. 71, 76 (1960). 
Assuming the validity of clauses purporting to reduce uninsured motorist insurance losses by the amounts paid and payable under workmen's compensation laws, it is next submitted that such a result is not necessarily reached under the Standard Form. The compensation clause of the Standard Form provides:

This endorsement does not apply ... (c) so as to inure directly or indirectly to the benefit of any workmen's compensation or disability benefits carrier or any person or organization qualifying as a self-insurer under any workmen's compensation or disability benefits law or any similar law. ${ }^{88}$

If the proceeds of uninsured motorist coverage ever actually inure to the benefit of a compensation carrier, this provision of the Standard Form has the effect of an excess clause in that payment under uninsured motorist coverage would be reduced by the amounts paid and payable by the compensation carrier. But if the proceeds of uninsured motorist coverage could never imure to the benefit of the compensation carrier even in the absence of section 11580.2 , the literally taken language of the Standard Form compensation clause has no effect, and the insured is entitled to recover the full amounts both under workmen's compensation and under the uninsured motorist coverage. Most insurance companies offering uninsured motorist coverage naturally adhere to the theory that payments under such coverage should be reduced by the amounts paid and payable by the compensation carrier. ${ }^{90}$ Thus far, no cases have passed on this question.

\section{Priority Between Compensation Carrier and Uninsured Motorist Insurer}

Where a workman having uninsured motorist coverage is injured in connection with his employment, payments to the insured (employee) will often be made both by the compensation carrier and the uninsured motorist insurer. Where both pay, both becoine subrogated to the insured's rights against the uninsured motorist to the extent of their respective payments. ${ }^{70}$ If the uninsured motorist is financially able to pay both, neither the uninsured inotorist insurer nor the compensation carrier will be financially harmed. But in the usual case, where the uninsured motorist has limited resources, both the compensation carrier and the uninsured motorist insurer will desire to have first claim to his assets. Here the compensation carrier clearly has the advantage since the Califorma Labor Code ${ }^{71}$ allows the compensation carrier a first hen against the judgment recovered by the insured against the third party tortfeasor. No conparable lien is afforded by statute or otherwise to the uninsured motorist insurer.

\section{Conclusion}

Of the three workmen's coinpensation problems discissed above, two can be answered with a reasonable degree of certainty by reference to statutes. The unresolved problem of whether the insured's recovery from the uninsured motorist insurer is reduced by his recovery from the compensation carrier is the result of ambiguous language in section 11580.2 and the Standard Form. ${ }^{72}$ If the legislature

68 Standard Form, Exclusions.

${ }^{69}$ Interview with Mr. M. J. Lucchesi, Divisional Superintendent of Claims, State Farm Mutual Automobile Ins. Co., in Berkeley, Calif., on April 13, 1960.

70 The uninsured motorist insurer becomes subrogated by virtue of CaL. INs. CodE $\$ 11580.2(\mathrm{e})$, and the compensation carrier becomes subrogated by virtue of CAL. LAB. CODE $\$ 83850-63$.

71 Cax. LaB. Code $883856-58$.

72 See tert at note 67 supro. 
intends to permit uninsured motorist insurers to reduce their losses by the amounts paid and payable by compensation carriers, a clarifying amendinent is in order. Meanwhile, insurers seeking to limit their losses under unimsured motorist insurance should modify their policies to conform to the language of the policy provision construed by the attorney general.

\section{H. Statute of Limitations-Tort or Contract?}

In California, the statute of limitations for actions based on written contracts is four years, ${ }^{73}$ and the statute of limitations for negligence actions is one year. ${ }^{74}$ Which statute applies to the insured's right of action against the insurer under the uninsured motorist endorsement?

One of the leading mutual insurers ${ }^{75}$ has taken the position that the one year tort statute applies. Its rationale is (1) that if the insured permits the one year statute of limitations to run upon his personal injury claim against the uninsured motorist, lie thereby destroys the insurer's right of subrogation, and (2) that if the insured allows the statute to run without filing suit, he is no longer legally entitled to recover damages from the uminsured motorist and hence no longer has a vahd claim under lis uninsured motorist coverage which insures only for sums the insured is legally entitled to recover. ${ }^{76}$

To this writer, it appears more likely that the four year contract statute of limitations applies to uninsured motorist claims against the insurer. The insurer's obligation to the insured arises not from a tort committed by an uninsured motorist, but from the contract of insurance.

The argument that the insured, by failmg to bring an action within one year has destroyed the insurer's right of subrogation and thereby forfeits his contract rights appears to be without nerit. The insured has no duty to the insurer to brimg an action against the uninsured notorist unless so requested by the insurer. Under the terms of the coverage, the insurer as well as the insured is entitled to initiate an action against the uninsured motorist. Therefore, the insurer itself lias permitted its subrogation claim to be destroyed if it has failed to file an action within the one year period of the statute of limitations. Since often the insured will not thimk it necessary to bring an action against the uninsured motorist because of the existence of uninsured motorist coverage, it would not be fair to allow an insurer to take refuge in the tort statute of limitations after the insured has been lulled into a false sense of security by reason of the coverage itself.

The argument that after the statute of himitations has run on the tort clain the insured is no longer legally entitled to recover damages from the uninsured motorist and hence no longer has a valid clain under his uninsured motorist coverage is not persuasive. Although uninsured notorist insurance insures only for sums which the insured shall be legally entitled to recover from the uninsured motorist, a reasonable construction of the language of section 11580.2(a) and the Standard Form leads to the conclusion that the coverage applies to sums legally recoverable from the uninsured motorist immediately following the accident and continues to apply even after the insured's remedy in tort is barred. Furthermore, even after

73 Car. Code Crv. Proc. \$337.

74 Car. Code Crv. Proc. \$340.

75 State Farm Mutual Automobile Ins. Co.

${ }^{76}$ Questions and Answers on Uninsured Motorist Coverage, (mimeographed), State Farm Mutual Automobile Ins. Co., Divisional Claims Superintendents' Conference, February 17-19, 1960, Panel Discussion on Uninsured Motorist Coverage. 
the tort statute of limitations has run, the insured still has a legal right to recover damages from the tortfeasor. The statute of limitations, although barring his remedy in tort, leaves unimpaired his alternate remedy against the insurer in contract.

Until this problem is resolved by the courts, however, the insured and his attorney should be careful to avoid the pitfall of the statute of limitations. An insured experiencing difficulty negotiating a settlement with the insurer should always file an action against the tortfeasor where it appears that negotiations with the insurer will not result in settlement within a year following the accident. In cases where the uninsured motorist is sufficiently solvent to make subrogation efforts worthwhile, the insurer likewise should file an action within one year if the insured has not done so, for by so doing the insurer can preserve its right of subrogation. But in the usual case, where the right of subrogation is nearly worthless because of the tortfeasor's insolvency, the insurer slould definitely not initiate action against the uninsured motorist, for by so doing the insurer would remove the statute of limitations issue from the case and thus destroy a part of its bargaining power in negotiations with the insured.

\section{Arbitration}

The Standard Form provides that certain future disputes which may arise between the imsurer and the insured under the policy shall be submitted to arbitration, ${ }^{77}$ and such an agreement to arbitrate is enforceable under California law. ${ }^{78}$ But prior to the enactment of section 11580.2, the law did not require that policies of uninsured motorist insurance had to provide for arbitration. Now, however, this section specifically states that policies or endorsements of uninsured motorist insurance shall provide "that the determination as to whether the insured shall be legally entitled to recover damages, and if so entitled the amount thereof, shall be made by agreement between the insured and the insurer, or in the event of disagreement, by arbitration." 79

Although section 11580.2 requires that policies shall provide for arbitration, details as to how the arbitration is to be conducted are left to the varions insurers. The contract of one of the leading mutual insurers provides that the insured and the insurer each shall select one arbitrator and that these two shall select a third, or in the event of disagreement, the third arbitrator is to be selected by a judge..$^{80}$ Under this contract, arbitration is conducted in accordance with the usual rules of procedure and evidence applicable to courts. The Standard Form, on the other hand, provides that the arbitration is to be conducted in accordance with the rules of the American Arbitration Association. ${ }^{81}$

Arbitration proceedings, lowever, are rare in uninsured motorist claims, since nearly all these claims are settled by negotiation and agreement between the insured and the insurer. Probably less than one percent of all uninsured motorist claims terminate in arbitration. ${ }^{82}$ But in those rare instances where arbitration is

77 Standard Form, Insuring Agreement $I$ and Condition 6.

i8 In California, arbitration is regulated by statute. CaL. Code Crv. Proc. $\$ \$ 1280-93$ legalize and make enforceable agreements to arbitrate future controversies arising out of an existing contract as well as agreements to arbitrate present controversies.

79 CaL. INs. Code $\$ 11580.2$ (d).

${ }^{80}$ State Farm Mutual Automobile Policy, Form 9515.2 California, Condition 15, p.6.

81 Standard Form, Condition 6. A pamphlet describing this procedure is available from the American Arbitration Association, 477 Madison Avenue, New York 22, New York.

82 Interview with Mr. M.J. Lucchesi, Divisional Superintendent of Claims, State Farm Mutual Automobile Ins. Co., in Berkeley, Calif, on April 13,1960. Of the approximately six 
destined to take place, certain problems peculiar to uninsured motorist insurance must be faced.

Arbitration of disputes under uninsured motorist coverage is limited to two issues: both the statute and the Standard Form provide for arbitration only of (1) the issue of the tortfeasor's legal liability to the insured and (2) the amount of the insured's damages. ${ }^{83}$ All other differences between the insured and the insurer which cannot be resolved by mutual agreement may be litigated in the courts. Thus it lias been held by a New York court, construing an arbitration provision substantially the same as that found in the Standard Form, that the question of whether or not a particular vehicle is an uninsured automobile is not left to arbitration under the terms of the policy. ${ }^{84}$

Because of the arbitration requirement, certain inconsistencies may be produced as a result of two separate tribunals deciding the same issues of law and fact. A board of arbitration might find that the uninsured motorist is liable to the insured, and a court might not, or vice versa. Thus, it is possible that the insurer might incur liabihty under the policy by virtue of the arbitrators' decision and subsequently be denied its right of subrogation by a court's judgment in favor of the uninsured motorist. Where the amount of damages is in controversy, moreover, it is extremely unlikely that the jury and the arbitrators would agree on the same sum.

Furthermore, the very existence of the arbitration requirement produces uncertainty as to the effect of a judgment upon the rights of the insured. For example, assume that the insured with the consent of the insurer prosecutes an action against the uninsured motorist to a favorable final judgment. At this point it is certain that the insured is legally entitled to recover a definite sum as damages from the uninsured motorist. May the insurer insist that the issues of liability and damages be redetermined by arbitration? If so, could the insured merely present his judgment to the arbitrators as conclusive evidence of liability and damages? If the insured's law suit against the uninsured motorist results in a judgment for the defendant, may the insured still insist that the issues of legal liability and damages be determined by arbitration? In such cases, it seems likely that the courts will find aubigmity in both section 11580.2 and the Standard Form and will resolve the ambiguity in favor of the insured. ${ }^{85}$

Since only an insignificant percentage of all urinsured motorist claims terminate in arbitration, and since the uninsured motorist is not bound by the arbitration proceedings, the arbitration requirement is nearly useless if its purpose is to remove litigation from the crowded dockets of the courts. When the insurer desires to preserve its subrogation riglits against the uninsured motorist, the insurer must resort to the courts in addition to arbitration, except where the uninsured motorist voluntarily agrees to reinburse the insurer. As the arbitration requirement will sometines result in litigating the same issues twice, once before the arbitrators and once before the court, arbitration seems to be peculiarly unsuited to the needs of uninsured motorist insurance. For these reasons, it would be

hundred uninsured motorist claims handled by Mr. Lucchesi's office to date, only one has terminated in arbitration.

83 CAx. INs. CODE $\S 11580.2$ (d); Standard Form, Insuring Agreement $I$ and Condition 6.

84 Application of American National Fire Ins. Co., 15 Misc. 2d 692, 182 N.Y.S.2d 899 (Sup. Ct. 1958).

85 For a similar view, see Morgenbesser, Some Legal Aspects of the New York Uninsured Motorists Coverage, 1956 INs. L.J. 241, 243. 
desirable if the arbitration requirements of the statute and the Standard Form were abolished.

\section{III}

\section{THE ADJUSTER IOOKS AT THE UNINSURED MOTORIST ENDORSEMENT}

\section{A. The Adjuster, the Insured, and the Uninsured Motorist}

In handling his first claim under the uninsured motorist endorsement, the claims adjuster is likely to find himself on unfamiliar ground where he is forced to assume a new and uncomfortable posture.

The adjuster's traditional attitude toward his insured is similar to that of a merchant desirous of maintaining good customer relations. The competent adjuster will often resolve disputed issues of fact and law in favor of the insured and will sometimes pay unjustified claims (especially where large accounts are at stake) in order to preserve good will and to retain the insured's patronage. If the adjuster's tact and persuasiveness fail to secure the cooperation of a disgruntled insured in providing the insurer with signed statements, medical reports, or other needed information, the adjuster may, as a last resort, invoke the cooperation clause of the policy.

When dealing with a third party claimant, as under bodily injury coverage, the adjuster assumes a somewhat different stance. There also he usually desires to develop the claimant's good will, but his motive is to secure the claimant's cooperation in the course of the investigation, to keep "control" of the case, ${ }^{86}$ and to obtain the lowest possible settlement of the claim. He regards the claimant as an adversary, and in dealing with him the capable adjuster resolves disputed issues of law and fact in favor of the insurance company for the purpose of denying liability or for securing a "rock-bottom" settlement. ${ }^{87}$

Which of these two attitudes ought the adjuster to assume when dealing with the policyholder having an uninsured motorist claim? The answer probably is neither. He should instead strike a careful balance between the two.

Under uninsured motorist coverage, the adjuster finds that the insured has become, to a very large extent, the claimant he is accustomed to dealing with under bodily injury coverage. As in the case of a bodily injury claimant, the insured under uninsured motorist coverage has the right to recover all of the usual special and general damages, including those for pain and suffering, provided that he establishes tort liability of the uninsured motorist. Likewise, the insurance company has available as a shield against its own insured the usual defenses of contributory negligence and assumption of risk. But an insured presenting an uninsured motorist claim to his own insurance company is likely to be far friendlier than a bodily injury claimant presenting his claim to an insurance company, because a bodily injury claimant identifies the insurance company with the individual who injured him. The adjuster should therefore take steps to preserve and cultivate this ready-made good will, which may later result in his obtaining a lower settlement than he would be able to effect in handling a similar claim under

86 I.e., to dissuade the claimant from obtaining legal counsel.

87 These and other conclusions in Part III are those of the commentator based on his personal experience as an adjuster with the San Francisco office of an insurance adjusting firm. 
bodily injury coverage. ${ }^{88}$ In bodily injury claims, the adjuster has only the good will of the injured party to aid him in obtaining the olaimant's statements and medical reports, but under the uninsured motorist coverage the injured party is bound to comply with the cooperation clause, ${ }^{89}$ to make statements under oath, to furnish the insurer with medical reports, and to submit to physical examinations by the insurance company's physician. ${ }^{90}$

\section{B. Investigation}

The actual investigation of an uninsured motorist claim should proceed very much the same as the investigation of a bodily injury claim under automobile liability insurance. The adjuster, however, should keep a few additional points in mind.

The very first thing to determine, of course, is whether or not an uninsured motorist claim exists, as this is a fact which often will not be known when a claim is first reported. Although such a determination will usually be a simple matter, at tines the adjuster will meet with complictations. For example, if the insurer of the other party denies coverage, the adjuster is faced with a potential uninsured motorist claim. When this occurs, he should consider the advisability of litigating the other insurer's denial of coverage, and nieanwhile he should conduct his investigation on the assumption that the other party is uninsured.

Once the adjuster determines that an uninsured motorist claim exists, he should next determine whether or not there exist any other policies of uninsured motorist insurance applicable to the injury. Such policies may be found in any of the following circuinstances: (1) where another policy of insurance is owned by the named insured; (2) where the injured party, who is a guest in the vehicle of the named insured, also owns a policy; (3) where the nanied insured is injured while riding in an automobile other than the one described in his policy and the owner of that automobile is similarly insured; or (4) where another member of the injured party's household owns a policy. If there is other applicable uninsured notorist insurance, it is possible that the loss nuay be pro-rated between the adjuster's company and another insurer, or that the loss may be borne by the other insurer altogether. ${ }^{\text {p1 }}$ The adjuster, therefore, should assemble lis information regarding other uninsured notorist imsurance in the early stages of his investigation so that he may give the other insurer pronipt notice, and so that le may make an early evaluation of the particular "other insurance" problem presented by the facts.

Also the adjuster should determine whether the insured was injured in the course of his employment, because if he were so injured, it is probable that workmen's compensation covers the injury. Where workmen's compensation is available it niay substantially reduce the amount of the loss which must be borne by the insurer affording uninsured motorist coverage. ${ }^{22}$

88 The experience of State Farm Mutual Automobile Insurance Co. in Northem California during 1959 was as follows: Cost of uninsured motorist coverage claims- $\$ 691.69$ per claim paid; cost of bodily imjury coverage claims- $\$ 1,334.33$ per claim paid. ("Claim" as used here means "file" and may include one or more claimants.) These statistics are based on an interview with Mr. M. J. Luchessi, Divisional Superimtendent of Claims, State Farm Mutual Automobile Ins. Co., in Berkeley, Calif., on April 13, 1960.

89 The Standard Form (Condition 1) makes the cooperation clause of the automobile hability policy applicable to the uninsured motorist endorsement.

- Standard Form, Condition 2.

91 See Part II, E, supra for a discussion of the complex "other insurance" problems.

22 See Part II, G, supra; Standard Form, Exclusion (c); CaI. Iss. Code \$ 11580.2 (c) (4). 
Where the uninsured motorist claim arises from a hit-and-run accident, the adjuster should determine a few additional facts. A hit-and-run automobile exists, for the purpose of uninsured motorist coverage, only when the identity of neither the owner nor the driver can be ascertained. ${ }^{93}$ Therefore, the adjuster should attempt to ascertain the identity of the owner or driver. Also, since an automobile qualifies as a hit-and-run automobile only if the insured or someone on his behalf has reported the accident within 24 hours to the police, a peace or judicial officer, or the Commissioner of Motor Vehicles, ${ }^{94}$ the adjuster should determine whether the insured reported the accident to the appropriate authorities within the proper time.

\section{Ethics}

As a result of uninsured motorist coverage, a new ethical problem faces the adjuster when dealing with the insured: namely, what duty does the adjuster have to notify the insured that an uminsured motorist claim exists and to solicit this claim? Where investigation reveals that the liability of the uninsured motorist is questionable but that injuries sustained by the insured are substantial, intelligent claims handhing would seem to dictate that the insured be contacted as early as possible regarding the uninsured motorist coverage and that a settlement be attempted. The ethical problem arises where investigation reveals that liability of the uninsured motorist is clear but that the injury to the insured is merely a technical one requiring no medical attention. One of the leating mutual insurance companies has attempted to answer this problem as follows:

[When uninsured motorist coverage may be involved] an exhaustive investigation should be made immediately. If after completing the investigation, it is believed that the insured should be paid under [uninsured motorist coverage] ... we should attempt settlement without waiting for a demand. ${ }^{95}$

The ethical adjuster faces an uncomfortable conflict of interest when the insurer is met with claims by an uninsured motorist for bodily injury or property damage and by the insured under the uninsured motorist endorsement. Assume, for example, that the insured has public liability and deductible collision coverage but no uninsured motorist coverage. The insured is seriously injured in an accident with an uninsured inotorist of ineager financial resources. The insured also suffers a major collision loss to which the insurer may become subrogated, if the uninsured motorist's liability to the insured can be established. The uninsured inotorist sustains minor property damage and no personal injuries. Here it is in the mutual interest of the insured and the insurer that the former win his negligence case against the uninsured motorist, and the adjuster naturally will assist the insured's attorney by conducting an investigation to discover witnesses and evidence which will corroborate the insured's version of the facts and to establish the hability of the uninsured motorist.

Now add these additional facts to the above hypothetical situation: the insured carries uninsured motorist insurance and makes a claim for $\$ 10,000$, the policy limit. If, prior to judgment in the insured's case against the uninsured motorist, the insured's claim under uninsured motorist coverage goes to arbitration ${ }^{96}$ and

83 Standard Form, Insuring Agreement II(d).

01 lbid.

95 Questions and Answers on Uninsured Motorist Coverage, (Inimeographed), State Farm Mutual Automobile Ins. Co., Divisional Claims Superintendents' Conference, February 17-19, 1960, Panel Discussion on Uninsured Motorist Coverage.

${ }^{o 6}$ See Part II, I supra. 
the arbitrators award $\$ 10,000$ to the insured, the insurer's total loss will be $\$ 10,000$ plus the amount of the insured's collision loss. To the extent of its loss the insurer will be subrogated to the rights of the insured against the uninsured motorist. But even if the uninsured motorist is financially able to pay a substantial portion of the subrogated claim, the insurer must still run the risk that in its action against the uninsured motorist judgment may be rendered in favor of the defendant. Because of this risk, it is in the interest of the insurer to orient its investigation towards the discovery of witnesses and evidence which will corroborate the uninsured motorist's version of the facts. If the adjuster can establish that the negligence of its insured caused the accident, the insurer must pay only the insured's collision loss plus the uninsured inotorist's property damage claim. Furthermore, if the adjuster can establish negligence on the part of both the insured and the uninsured motorist, the insurer must pay only the insured's collision loss. Thus there is a sharp conflict of interest between the insured and the insurer which is due solely to the existence of uninsured motorist coverage.

Although it may be initially in the best interest of the insurer to take action to defeat the insured's clain against the uninsured motorist, the adjuster pursuing this course of action must be prepared to do some rather awkward fence jumping. For if in the above fact situation the insured does obtain an arbitration award against the insurer, the interests of the insured and the insurer once again become united in their efforts to defeat the urninsured motorist. Their alliance, however, may be jeopardized by the insured's natural feehings of lostility towards lis recent adversary, the insurance company, and is likely to be short-lived since a judgment against the uninsured notorist may set them to quarreling over distribution of the proceeds. ${ }^{97}$

\section{IV}

\section{CONCLUSION}

The great increase in the number of motor vehicles on California's streets and higlwways has accented the problen of the financially irresponsible motorist. California's Financial Responsibility Law does not require proof of ability to pay damages until after the uninsured motorist's first reportable accident and by itself is an imperfect solution to the problem.

The enactment of California Insurance Code section 11580.2 is a major step towards resolving the problem of the financially irresponsible motorist. This new statute requires insurers issuing policies of liability insurance in California to provide additional coverage guaranteeing the payment of the insured's damages for personal injuries legally recoverable from an uninsured motorist. The Financial Responsibility Law, together with section 11580.2, constitutes California's present solution of the problem of the uninsured motorist.

This solution, however, has generated new problems of its own. Some of these problems result from ambiguities found in insurance policy provisions and others are inherent in the nature of uninsured motorist insurance. Others yet are the product of the interaction of the new statute and the Standard Form uninsured motorist endorsement. The legislature can eliminate many of the latter problems by enacting appropriate amendments to the new-statute.

California's solution of the problem of the uninsured motorist has many advantages to offer over the various solutions attempted by sister states. Under the new 
statute, uninsured motorist insurance is nearly universal with insured motorists, yet it is completely voluntary and preserves private enterprise in the insurance business. Also it provides substantial protection for a modest premium. Other jurisdictions will do well to follow California by enacting legislation designed to encourage voluntary uninsured motorist insurance.

Harry Edgar Rice III*

* Member, Class of 1960. 


\section{APPENDIX A}

\section{Catmorantu Insurance Code $\$ 11580.2$}

required

policy provisions

waiver by supplemental agreement

"bodily injury" defined

"insured" defined

"uninsured motor vehicle" defined

exemptions property damage

"other insurance" clause

insured required to obtain consent

workmen's compensation (a) No policy of bodily injury liability insurance covering liability arising out of the ownership, maintenance, or use of any motor vehicle, shall be issued or delivered in this State to the owner or operator of a motor vehicle, or shall be issued or delivered by any insurer licensed in this State upon any motor vehicle then principally used or principally garaged in this State, unless the policy contains, or has added to it by endorsement, a provision insuring the named insured and any other person legally responsible for the use of or using the motor vehicle with the consent, express or implied, of the named insured, for all sums which he shall be legally entitled to recover as damages for bodily injury from the owner or operator of an uninsured motor vehicle, with coverage limits at least equal to the financial responsibility requirements specified in Sections 16059 and 16451 of the Vehicle Code; provided, however, that the insurer and the insured may by supplemental agreement waive application of the provision covering damage caused by an uninsured motor vehicle.

(b) As used in (a) above, "bodily injury" shall include sickness or disease, including death, resulting therefrom; the term "insured" means the named insured and the spouse of the named insured and relatives of either while residents of the same household while occupants of a motor vehicle or otherwise, and any other person while in or upon or entering into or aligliting from an insured motor vehicle; provided, the motor vehicle is used by the named insured or with his permission or consent, express or implied; the term "uninsured motor vehicle" means a motor velicle with respect to the ownership, maintenance or use of which there is no bodily injury liability insurance or bond applicable at the time of the accident or a motor vehicle used without the permission of the owner thereof if there is no bodily injury liability insurance or bond applicable at the time of the accident with respect to the operator thereof, or there is such applicable insurance or bond but the company writing the same denies coverage thereunder, or the owner or operator thereof be unknown. The term "uninsured motor vehicle" shall not include an automobile owned by the named insured or any resident of his household or selfinsured within the meaning of the safety responsibility law of the state in which the motor vehicle is registered or which is owned by the Umited States or Dominion of Canada, or any state or province or any agency or political subdivision of any of them, or a land motor vehicle or trailer operated on rails or crawler-treads or while located for use as a residence or premises ant not as a vehicle.

(c) The insurance coverage provided for in this section does not apply:

(1) To property damage sustained by the insured.

(2) To bodily injury of the insured sustained while in or upon or while entering into or alighting front an automobile other than the described autounobile if the owner thereof has insurance similar to that provided in this section.

(3) To bodily injury of the insured with respect to which such insured or his representative shall, without the written consent of the insurer, make any settlement with or prosecute to judgment any action against any person who may be legally liable therefor.

(4) In any instance where it would inure directly or indirectly to the benefit of any workunen's colnpensation carrier or to any person qualified as a self-insurer under any workmen's compensation law. 
arbitration

"limits"

defined

subro-

gation

reimburse-

ment of

insured

no-waiver

clause (d) The policy or an endorsement added thereto shall provide that the determination as to whether the insured shall be legally entitled to recover damages, and if so entitled, the amount thereof, shall be made by agreement between the insured and the imsurer or, in the event of disagreement, by arbitration. As used in (a) above, "limits" small mean for purposes of this section a liability limit, on account of bodily injury sustained by one insured as a result of any one accident, or sustained by two or more persons in any one accident, consistent with the limits of liability referred to in the provisions concerning financial responsibility and security following accidents found in Division 7 (commencing with Section 16000) of the Vehicle Code.

(e) An insurer paying a claim under an uninsured motorist endorsement - or coverage shall be entitled to be subrogated to the rights of the msured to whom such claim was paid against the person causing such injury or death to the extent that payment was made.

(f) An insured entitled to recovery under the uninsured motorist endorsement or coverage shall be reimbursed within the conditions stated herein without being required to sign any release or waiver of rights to which he may be entitled under any other insurance coverage applicable, nor shall payment under this section to such insured he delayed or made contingent upon the decisions as to liability or distribution of loss costs under other bodily imjury liability insurance or any bond applicable to tlie accident. (added by Cal. Stat. 1959 , ch. 817 , p. $2835, \S 1$. )

\section{APPENDIX B \\ Other Insurance Provisions of the Statute and the Stamdard Form}

The Statute:

CAL. INS. CODE § 11580.2 (c) (2)

Escape

Clause

Paragraplı (1)

Excess

Clause

Escape

Clause

Paragrapl (2)

Pro-rata

Clause

Paragraph (3)

Pro-rata

Clause
The insurance coverage provided for in this section does not apply: ... . (2) to bodily injury of the insured sustained while in or upon or while entering into or alighting from an automobile other than the described automobile if the owner thereof las insurance similar to that provided in this section.

\section{THE Standard Form:}

\section{Condition 5 (three paragraphs)}

With respect to bodily injury to an insured while occupying an automobile not owned by a named insured under tbis endorsement, the insurance liereunder shall apply only as excess over any other similar insurance available to such occupant,

and this insurance shall then apply only in the amount by which the applicable limit of liability of this endorsement exceeds the sum of liability of all such other insurance.

With respect to bodily injury to an insured while occupying or through being struck by an uninsured automobile, if suclt insured is a named insured under similar insurance available to him the danrages shall be deemed not to exceed the higlier of the applicable limits of hability of this insurance and such other insurance, and the company shall not be liable under this endorsement for a greater proportion of the applicable liability of this endorsement than such limit bears to the sum of the applicable limits of this insurance and such other insurance.

Subject to the foregoing paragrapls, if the insured has other similar insurance available to him against a loss covered by this endorsement, the company shall not be liable under this endorsement for a greater proportion of such loss than the applicable limit of liability hereunder bears to the total applicable limits of liability of all valid and collectible insurance against such loss. 